\title{
Monitoring and Evaluation Practices and Project Performance in Rwanda: A Case of the Horticulture Project at BRAMIN Ltd
}

\author{
Doreen UMWARI ${ }^{1}$, Dr. Kant James KAMUHANDA ${ }^{2}$ and \\ Nathan M. NYAMWEYA ${ }^{3}$
}

\author{
${ }^{1,2,3}$ School of Business and economic, Mount Kenya University,Kigali, Rwanda
}

\begin{abstract}
Monitoring and evaluation is acomprehensive requirement for most of the projects to performance despite a huge amount of resources need to implement and enhance project performance. Projects in Africa are faced with so many monitoring and evaluation related problems which result into unsatisfactory outcome in productive business organizations. In Rwanda, monitoring and evaluation is not carried out effectively and this has led to so many business organizations to achieve less output than expected. Monitoring and evaluation is very costly, therefore it is applied in strong and competitive companies. As far as the Horticulture project at BRAMIN Ltd is concerned, the observation is that monitoring and evaluation is of poor quality and this may result into crucial impact on project performance and low investment return and hence employees' demotivation. It is in this regard the researcher has conducted a study about how the effect of monitoring and evaluation on performance of the horticultural project at BRAMIN Ltd in order to establish a relationship between the monitoring, evaluation and performance of the Horticulture project with BRAMIN Ltd. A descriptive research design with a mixed method of qualitative and quantitative data was used in this study to gather data from 102 respondents with the use of the census as a sampling technique. The analysis of the collected information was analyzed with the use of the Pearson correlation and the analysis of multiple linear regressions with the use of the SPSS 21.0 and the results are presented in both tables and figures. Findings of results have shown a significant relationship between monitoring and evaluation and the performance of horticulture project, for instance the positive and significance relationship between budgeting and timely completion of the project $(\mathrm{p}=.755$ and $\mathrm{sig}=.000)$, and that one between Budgeting and level of satisfaction of beneficiaries $(\mathrm{p}=.754$ and $\mathrm{sig}=.000)$
\end{abstract}

since all calculated $\mathrm{p}$ - values are less than 0.01 value level. Basing on the findings of the study this research concludes that is a positively significant relationship between monitoring and evaluation and performance of project.

\section{Introduction}

Since the ancient time monitoring and evaluation practices were applied all over the world. Thus this has attracted the modern civilization to apply monitoring and evaluation system as means of management tools for companies' financial performance which is needed to meet the stakeholders related demand in terms of accountability, transparency (Gorgens\&Kusek, 2009).

The concept of monitoring refers to a regular function that aims at providing the management channel related to the ongoing of business activities within companies or other productive institutions. The purpose of monitoring activity is to ensure whether the institution progress is being observed or if the intended results are achieved. The progress may be evaluated in terms of programmes, new projects or assistance to achieve desired outcomes(FHI, 2004).

The monitoring and evaluation of the projects is basically based on analysis and responding to risks so as to ensure the continuity of institution projects. To make sure that institution's projects are performed, there should be different ways of strengthening the capacity of the company or institution, the households, community, formal or informal business organs to achieve the desired outcome (IFAD, 2005).

The project performance needs to be planned before therefore, monitoring and evaluation requires the establishing scope of efforts, determining and identifying objectives to be achieved, and developing the course of action to be achieved (Zwikael\&Smyrk, 2015). Monitoring and 
evaluation practices provide the essential factors that help the project to face great improvement and developments in complex companies and organizations with multidisciplinary operations and intensive processes (Jaszczolt, et al., 2010). The global movement of monitoring and evaluation has shown symbolic performance of projects not only in the projects conducted in developed countries but also in less developed countries.

Even if monitoring and evaluation present significant contribution to so many project performance, in many projects whether profit making organization, nonprofit making organization or companies still face projects related to insufficient material support, managerial skills, technical skills, human skills and financial constraints which call for intervention (Kusek, et al., 2004).

In Africa, monitoring and evaluation is important as this zone is determined by high risks with difficult areas which are sometimes dangerous for business operations. Monitoring and evaluation is sometimes complicated for many business holders and this result into slow projects performance. Therefore Africa is a challenging continent but there still market opportunities which call up business investors to implement policies and regulations (Du Plessis, 2005).

According to (Muller and Turner, 2010), most projects operating in Africa are complex in nature due to structure of the continent which bring about failure of some projects. The problems are usually related to budget constraints, poor technology and insufficient management skills. The problems that continue to arise affect growth and development of the continent.

In east Africa specifically in Tanzania, most of projects are not performing due to managerial skills which constitute the barriers to the management not to put more efforts on the practices of monitoring and evaluation that are beneficial in order to increase the desired outcome. Monitoring in East Africa is not of quality since and sometimes is conducted by low skilled experts (Crawford \&Nahmias , 2010 ).

In Rwanda, monitoring and evaluation represents the low quality and this affects projects performance. However, the application of monitoring and evaluation in Rwanda remains for the strong companies and this has called the government to encourage most of productive organizations apply $\mathrm{M} \& \mathrm{E}$ system as tool of performance process (GoR, 2010).

\subsection{Objectives of the study}

\subsubsection{General objective}

The general objective of this research was to investigate the role of monitoring and evaluation

\section{ISSN 2455-6378}

practices in enhancing the performance of the horticultural project at BRAMIN ltd in Rwanda.

\subsubsection{Specific objectives}

(i) To assess the influence on of monitoring and evaluation practices in the horticulture project at BRAMIN ltd.

(ii) To determine the benefits of project performance in horticulture project at BRAMIN ltd.

(iii) To find out the connection between M\&E practices and project performance of the Horticulture Company at BRAMIN ltd.

\section{Review of Literature}

A study by Prabhakar (2008), in United Kingdom on his study what is Project Success pointed out that monitoring and observations had been one of the elements that led to the performance of project and it also referred to that the likelihood of attaining the frequent overall performance of the project is considered to lengthen between one-ofa-kind factor, which constantly help to monitor the progress of the project. This study considers monitoring and evaluation as a significant practice and application in scrutinizing and managing the project scope, cost, human resource, communication and quality.

Another study, carried out by Prabhakar (2008) in the UK, indicated that monitoring the assessment finances needs to be included and developed in the common funds of the allocation to furnish the follow-up and distinction characteristic of their dedication due to their proximity in task management. Monitoring and evaluation are an indispensable section of the projects management cycle that entails planning and outlining the matters that want to be performed about the initiatives in view of implementation. Project planners choose to align monitoring and contrast troubles to do so with the allocation plan with these factors encompassing human sources to amplify evaluations, frequency, and rate vary of deliberate activities, and hassle heritage as well as the specification.

Abalang (2016) conducted research on employee's job performance on monitoring and evaluation systems in South Sudan at Caritas Torit. The outcomes of the project targeted on how teams and strategies have impacted administration and budgets, stakeholder participation, and team of workers coaching have an effect on the usual typical work carried out during and after the project. Both observational and quantifiable files had been collected; Quantifiable documents on the use of descriptive statistics have been analyzed and qualitative data have been analyzed the use of content analysis. The findings shown that most respondents had been no longer M\&E 
professionals and then had their advantage in job training (OJT), which used to be so applauded. The consequences of the study helped inspire the provision of specialized $M \& E$ training to employees.

Wanjiru (2013) has made a good note that regarded the determinants of the big control and contrast computing device in NGOs in Nairobi, Kenya. Thus, observational and quantifiable records have been accrued and analyzed the usage of correlation and regression analysis. The effects showed that $69.15 \%$ of the respondents attended the coaching and that used to be very entirely and excellent understood, advocating that the education courses be coordinated in the course of the NGO region to encourage the induction of specialists in M\&E of the neighborhood to do the fantastic. M \&amp; amp; properly equipped with all the expertise and capabilities wanted to monitor and evaluate projects.

In Uganda, statistics performed with the assist of Nasambu (2016) on the elements affecting the frequent usual overall performance of monitoring and comparison constructions in nongovernmental corporations in northern Uganda, Lira District, installed that respondents had acquired the imperative coaching at $\mathrm{M}$ \&amp; amp; E. The conclusions of the project shown that the timely completion of the organization has $64.0 \%$ of the effect on the overall performance of initiatives carried out through non-governmental corporations in Lira. Jones (2011), in addition, performed a follow-up-related gaining knowledge of that posted that the crews of people with relevant skills, terrific sources, and transparency have a remarkable influence on universal assignment performance. The study additionally indicated a good sized connection between $\mathrm{M} \& \mathrm{E}$ and the project performance.

\section{Materials and Methods}

The descriptive research design was used in this study to explain how the information was

4.1 The influence of monitoring and evaluation practices in the horticulture project at BRAMIN Itd Table 4.1: Statement regarding the extent to which budgeting in monitoring and evaluation practices influence performance of the Horticulture project at BRAMIN Itd

\begin{tabular}{llllllll}
\hline Statements & 5 & 4 & 3 & 2 & 1 & Mean & Std. \\
\hline $\begin{array}{l}\text { BRAMIN Ltd allocates a budget } \\
\text { for monitoring activities to } \\
\text { facilitate project performance }\end{array}$ & $2(2.0 \%)$ & $5(4.9 \%)$ & $9(8.8 \%)$ & $35(34.3 \%)$ & $51(50.0 \%)$ & 1.745 & .951 \\
$\begin{array}{l}\text { Budget allocated for monitoring } \\
\text { activities is sufficient to achieving } \\
\text { project performance }\end{array}$ & $2(2.0 \%)$ & $5(4.9 \%)$ & $12(11.8 \%)$ & $30(29.4 \%)$ & $53(52.0 \%)$ & 1.754 & .979 \\
$\begin{array}{l}\text { Insufficient budget allocation for } \\
\text { monitoring activities are related to } \\
\text { poor project performance }\end{array}$ & $2(2.0 \%)$ & $6(5.9 \%)$ & $9(8.8 \%)$ & $38(37.3 \%)$ & $47(46.1 \%)$ & 1.803 & .965 \\
Overall mean & & & & & & & \\
\end{tabular}

Source: Research Data, 2021 collected, prepared and carried out in detail with help of Pearson correlation analysis and multi linear regression analysis which were used to analyze the collected data. The use of research design is study by the literatures of Bogere (2015) who asserted that research design is the organization of skills together with strategies so a obtain data for a study. Thus, in this research, the quantitative component was determined by administration of research questionnaire among respondents of BRAMIN ltd to get statistical data. Therefore, closed ended questionnaire were developed to facilitate respondents pick one best response.

The whole target population of 102 of M\&E was involved in the study as sample size because this study was manageable in time and finance implying that census method were used. Thus, the 4 respondents in managerial section of BRAMIN ltd were given interview while other 98 respondents were given questionnaire to fill and they were all returned.

After collecting data researcher analyzed quantitative data through statistical package for social sciences (SPSS) version 21.0 that assisted in getting descriptive statistical data and inferential statistics were used through the use of Pearson correlation analysis and multiple linear regression analysis where $Y=\beta_{0}+\beta_{1} X_{1}+\beta_{2} X_{2}+\beta_{3} X_{3}+\varepsilon$ as per the analysis the $Y$ represents the independent variable which is monitoring and evaluation, $\beta_{0}$ is the constant, $\beta 1, \beta 2$ and $\beta 3$ as coefficients of determination while $X_{1}, X_{2}$, and $X_{3}$ are the indicators of project performance which are budgeting, training and accountability.

\section{Results and Discussion}

The response rate show the rate of collected questionnaires, the total sample selected from horticulture project at BRAMIN ltd was 102 $(100.0 \%)$ respondents form different departments.
Source: Research Data, 2021 
The results in Table 4.6 of the study show an overall mean of 1.7696 which implies that the results of this research confirm that budgeting in monitoring and evaluation practices affects performance of horticulture at BRAMIN ltd. Thus, the results of the current study are supported by the study of Abalang (2016) which were conducted as a research on the Evaluation of Performance of Monitoring and Evaluation Systems in South Sudan, at Caritas Torit. The study has also shown that equipment and
ISSN 2455-6378

methods, impact budgeting and management, education of employees and stakeholders involvement have an effect on performance of M\&E systems. The findings have additionally revealed that most of the respondents were not aware of M\&E practices however received their competencies through on job training (OJT) which used to be noticeably applauded. The project advocated for provision of professional M\&E capacity building to the personnel.

Table 4.2: Statements regarding the benefits of monitoring and evaluation on the performance of the Horticulture project at BRAMIN Ltd.

\begin{tabular}{|c|c|c|c|c|c|c|c|}
\hline Statements & 5 & 4 & 3 & 2 & 1 & Mean & Std. \\
\hline $\begin{array}{l}\text { Accountability in project enhances } \\
\text { M\&E process to achieve project } \\
\text { performance }\end{array}$ & $2(2.0 \%)$ & $6(5.9 \%)$ & $9(8.8 \%)$ & $33(32.4 \%)$ & $52(51.0 \%)$ & 1.754 & .979 \\
\hline $\begin{array}{l}\text { Risks analysis improves } \mathrm{M} \& \mathrm{E} \\
\text { process to achieve project } \\
\text { performance }\end{array}$ & $2(2.0 \%)$ & $6(5.9 \%)$ & $9(8.8 \%)$ & $37(36.3 \%)$ & $48(47.1 \%)$ & 1.794 & .968 \\
\hline $\begin{array}{l}\text { Training in M\&E process helps to } \\
\text { achieve project performance }\end{array}$ & $2(2.0 \%)$ & $6(5.9 \%)$ & $9(8.8 \%)$ & $18(17.6 \%)$ & $67(65.7 \%)$ & 1.607 & 1.006 \\
\hline $\begin{array}{l}\text { The activities of M\&E present } \\
\text { significant benefits in project } \\
\text { performance }\end{array}$ & $2(2.0 \%)$ & $6(5.9 \%)$ & $16(15.7 \%)$ & $31(30.4 \%)$ & $47(46.1 \%)$ & 1.872 & 1.011 \\
\hline Overall mean & & & & & & 1.757 & \\
\hline
\end{tabular}

Source: Research Data, 2021

The Table 4.2 indicates the overall means is 1.757 which tends towards strongly agree which implies that monitoring and evaluation is beneficial to project performance of Horticulture project at BRAMIN ltd which is support by the findings of Nasambu (2016) who revealed that timely completion of the project at $64.0 \%$ is affected by project performance in Non Governmental organization projects in Uganda, Lira District.

Table 4.3: Statement regarding how training of Monitoring and Evaluation experts promotes project performance

\begin{tabular}{llllllll}
\hline Statements & $\mathbf{5}$ & $\mathbf{4}$ & $\mathbf{3}$ & $\mathbf{2}$ & $\mathbf{1}$ & Mean & Std. \\
\hline $\begin{array}{l}\text { Training in M\&E assist in } \\
\text { project performance }\end{array}$ & $2(2.0 \%)$ & $5(4.9 \%)$ & $12(11.8 \%)$ & $34(33.3 \%)$ & $49(48.0 \%)$ & 1.794 & .9681 \\
$\begin{array}{l}\text { Training intervals are important } \\
\text { to empower staff skills in M\&E }\end{array}$ & $2(2.0 \%)$ & $5(4.9 \%)$ & $9(8.8 \%)$ & $17(16.7 \%)$ & $69(67.6 \%)$ & 1.568 & .9801 \\
$\begin{array}{l}\text { for project performance } \\
\begin{array}{l}\text { Staff trainings in M\&E enhance } \\
\text { project performance }\end{array}\end{array}$ & $2(2.0 \%)$ & $6(5.9 \%)$ & $9(8.8 \%)$ & $36(35.3 \%)$ & $49(48.0 \%)$ & 1.784 & .9711 \\
\begin{tabular}{l} 
Overall mean. \\
\hline
\end{tabular} & & & & & 1.715 &
\end{tabular}

\section{Source: Research Data, 2021}

The Table 4.3 indicate an overall mean is 1.7156 which implies that training the experts in manipulate and contrast desire the universal performance of the horticulture project at BRAMIN ltd which is supported by the results of the study of Wanjiru (2013) whose findings have revealed that $69.15 \%$ of respondents had attended college and used to be exhaustive and stated that education was coordinated through NGOs to motivate the induction of close $M \& E$ specialists to extend of M\&E team. 
Table 4.4: Statements regarding accountability and project performance

\begin{tabular}{|c|c|c|c|c|c|c|c|}
\hline Statements & 5 & 4 & 3 & 2 & 1 & Mean & Std. \\
\hline $\begin{array}{l}\text { Accountability for activities and } \\
\text { decisions in the } M \& E \text { process } \\
\text { promote project performance }\end{array}$ & $2(2.0 \%)$ & $6(5.9 \%)$ & $16(15.7 \%)$ & $18(17.6 \%)$ & $60(58.8 \%)$ & 1.745 & 1.050 \\
\hline $\begin{array}{l}\text { Accountability assists in } \\
\text { resources allocation and resource } \\
\text { management during the project } \\
\text { life cycle for project performance }\end{array}$ & $2(2.0 \%)$ & $6(5.9 \%)$ & $12(11.8 \%)$ & $31(30.4 \%)$ & $51(50.0 \%)$ & 1.794 & .998 \\
\hline $\begin{array}{l}\text { Accountability during } \\
\text { process ensures } \\
\text { performance }\end{array}$ & $2(2.0 \%)$ & $6(5.9 \%)$ & $11(10.8 \%)$ & $20(19.6 \%)$ & $63(61.8 \%)$ & 1.666 & 1.017 \\
\hline Total mean. & & & & & & 1.735 & \\
\hline
\end{tabular}

\section{Source: Research Data, 2021}

The Table 4.4 indicates an overall mean of 1.7353 which implies that the tendency of the respondents' opinions affirms that accountability promotes project performance and these results of the current study are supported by the results of the study of Jones
(2011) who proved that monitoring and evaluation is conducted by skilled staffs with enough resource, accountability and transparency in order to be quality.

\subsection{The benefits of project performance in horticulture project at BRAMIN Itd.}

Table 4.5: Statements regarding performance of horticulture project in BRAMIN Ltd

\begin{tabular}{|c|c|c|c|c|c|c|c|}
\hline Perceptions & 5 & 4 & 3 & 2 & 1 & Mean & Std. \\
\hline $\begin{array}{l}\text { Cost estimation in } \\
\text { project prorticulture } \\
\text { performance }\end{array}$ & $2(2.0 \%)$ & $6(5.9 \%)$ & $9(8.8 \%)$ & $16(15.7 \%)$ & $69(67.6 \%)$ & 1.588 & 1.008 \\
\hline $\begin{array}{l}\text { Cost effectiveness promotes project } \\
\text { performance }\end{array}$ & $2(2.0 \%)$ & $6(5.9 \%)$ & $9(8.8 \%)$ & $16(15.7 \%)$ & $69(67.6 \%)$ & 1.588 & 1.008 \\
\hline $\begin{array}{l}\text { Timely completion of the project } \\
\text { promote project performance }\end{array}$ & $2(2.0 \%)$ & $7(6.9 \%)$ & $14(13.7 \%)$ & $23(22.5 \%)$ & $56(54.9 \%)$ & 1.784 & 1.049 \\
\hline $\begin{array}{l}\text { There is relationship between cost } \\
\text { effectiveness and project } \\
\text { performance }\end{array}$ & $2(2.0 \%)$ & $6(5.9 \%)$ & $12(11.8 \%)$ & $17(16.7 \%)$ & $65(63.7 \%)$ & 1.656 & 1.029 \\
\hline $\begin{array}{l}\text { The quality of products/ outcome is } \\
\text { a measure of the success of the } \\
\text { horticulture project }\end{array}$ & $2(2.0 \%)$ & $7(6.9 \%)$ & $14(13.7 \%)$ & $23(22.5 \%)$ & $56(54.9 \%)$ & 1.784 & 1.049 \\
\hline $\begin{array}{l}\text { Satisfaction of beneficiaries } \\
\text { enhance project performance }\end{array}$ & $1(1.0 \%)$ & $6(5.9 \%)$ & $9(8.8 \%)$ & $35(34.3 \%)$ & $51(50.0 \%)$ & 1.735 & .921 \\
\hline $\begin{array}{l}\text { The level of customer satisfaction } \\
\text { depends on the quality of the } \\
\text { outcome of the project }\end{array}$ & $2(2.0 \%)$ & $7(6.9 \%)$ & $9(8.8 \%)$ & $36(35.3 \%)$ & $48(47.1 \%)$ & 1.813 & .992 \\
\hline $\begin{array}{l}\text { The quality of products and cost } \\
\text { minimization is a measure of } \\
\text { project performance }\end{array}$ & $1(1.0 \%)$ & $6(5.9 \%)$ & $9(8.8 \%)$ & $35(34.3 \%)$ & $51(50.0 \%)$ & 1.735 & .921 \\
\hline Overall mean & & & & & & 1.710 & \\
\hline
\end{tabular}

\section{Source: Research Data, 2021}

Table 4.5 indicate that the overall mean of 1.7107 which shows a strong tendency towards the strongly agree score which implies that there is performance of horticulture project at BRAMIN ltd which is supported by the study of Nasambu (2016) which were conducted in Lira Disrtict, Uganda on monitoring and evaluation and project performance showed that timely completion of the project affect project performance at $64.0 \%$ in Non-government organization projects 
4.3 The relationship between monitoring and evaluation and performance of Horticulture project at BRAMIN Itd

Table 4. 6: Correlation analysis between $M \& E$ and performance of horticulture project

\begin{tabular}{lllll}
\hline & & Cost effectiveness & $\begin{array}{l}\text { Timely completion of the Level of satisfaction of } \\
\text { project } \\
\text { beneficiaries }\end{array}$ \\
\hline \multirow{4}{*}{ Budgeting } & Pearson Correlation & $.724^{* *}$ & $.755^{* * *}$ & $.754^{* * *}$ \\
& Sig. (2-tailed) & .000 & .000 & .000 \\
& $\mathrm{~N}$ & 102 & 102 & 102 \\
Training & Pearson Correlation & $.878^{* *}$ & $.909^{* *}$ & $.903^{* *}$ \\
& Sig. (2-tailed) & .000 & .000 & .000 \\
& $\mathrm{~N}$ & 102 & 102 & 102 \\
& Pearson Correlation & $.890^{* *}$ & $.895^{* *}$ & $.918^{* *}$ \\
Accountability & Sig. (2-tailed) & .000 & .000 & .000 \\
& $\mathrm{~N}$ & 102 & 102 & 102
\end{tabular}

**. Correlation is significant at the 0.01 level (2-tailed).

Source: Research Data, 2021

This Table 4.6 proves that there is a relationship between monitoring and evaluation and project performance, for instance the positive and significant relationship between budgeting and cost effectiveness $(\mathrm{p}=.724$ and $\operatorname{sig}=.000)$, and that one between budgeting and timely completion of the project $(\mathrm{p}=.755$ and $\mathrm{sig}=.000)$ due to the fact all $\mathrm{p}$ - values calculated are less than 0.01 degree of significance. Thus, the findings of this study supported by the Jones (2011) who carried out a study on relevant body of workers skills, appropriate resources and transparency to be kind, as there is a positive correlation between monitoring and evaluation and project performance.

Table 4.7: Model Summary of M\&E and cost effectiveness

\begin{tabular}{clll}
\hline Model R & $\begin{array}{l}\mathrm{R} \\
\text { Square }\end{array}$ & $\begin{array}{l}\text { Adjusted } \\
\text { Square }\end{array}$ & RStd. Error of the Estimate \\
\hline $.892^{\mathrm{a}} .796$ & .789 & .43987 \\
\hline
\end{tabular}

a. Predictors: (Constant), Accountability, Budgeting, Training

Source: Research Data, 2021

This Table 4.7 proves that the coefficient $\mathrm{R} .892$ suggests that $\mathrm{M} \& \mathrm{E}$ is associated with the monitoring and evaluation and cost-effectiveness of project performance in Rwanda. The coefficient of determination $.796 \mathrm{R}$ square also shows that $\mathrm{M} \& \mathrm{E}$ explains $79.6 \%$ of the variability of development in the cost-effectiveness of task monitoring and comparison and performance in Rwanda. Therefore, it insinuates that the inputs variables of $M \& E$, for example accountability, budgets and training, which have an effect on the improvement of $79.6 \%$ of the cost-effectiveness of monitoring and evaluation and assignment overall performance Rwanda.

Table 4.8: Analysis of Variance (ANOVA) of M\&E and cost effectiveness

\begin{tabular}{llllll}
\hline Model & Sum of Squares & Df & Mean Square & F & Sig. \\
\hline Regression & 73.862 & 3 & 24.621 & 127.248 & $.000^{\mathrm{b}}$ \\
Residual & & 18.96298 & .193 & & \\
Total & 92.824 & 101 & & & \\
\hline
\end{tabular}

a. Dependent Variable: Cost effectiveness

b. Predictors: (Constant), Accountability, Budgeting, Training

Source: Research Data, 2021

Findings in the Table 4.8 suggests that monitoring and evaluation has a significant relationship with cost effectiveness due to calculate significance values of .000 which is lesser than 0.05 level of significance. Hence, a connection between monitoring and evaluation and cost effectiveness as 
variable of Project Performance in horticulture

project at BRAMIN ltd, Rwanda.

Table 4. 9: Coefficients of $M \& E$ and cost effectiveness

\begin{tabular}{lllllll}
\hline Model & \multicolumn{2}{l}{ Unstandardized Coefficients } & Standardized Coefficients & T & \multirow{2}{*}{ Sig. } \\
\cline { 2 - 5 } & $\mathrm{B}$ & Std. Error & Beta & & 6.297 & .000 \\
\hline (Constant) & .523 & .083 & & 1.038 & .002 \\
Budgeting & .089 & .086 & -.091 & .875 & .003 \\
Training & .213 & .243 & .213 & 3.254 & .002 \\
Accountability & .731 & .225 & .757 & & 3 \\
\hline
\end{tabular}

a. Dependent Variable: Cost effectiveness

Source: Research Data, 2021

The Table 4.9 has demonstrated that variables of M\&E has positive coefficients that strengthen positive effect on the progress of cost effectiveness in monitoring and evaluation and project performance as it is represented by regression model, $\mathrm{Y}=\beta 0+\beta 1 \mathrm{X} 1+\beta 2 \mathrm{X} 2+\beta 3 \mathrm{X} 3+\varepsilon \quad$ which becomes $\mathrm{Y}=0.523+.089 \mathrm{X} 1+.213 \mathrm{X} 2+.231 \mathrm{X} 3$ and confirms a positive and significance relationship between $M \& E$ practices and Project Performance in Rwanda.

The relationship also between budgeting and cost effectiveness proves that there is a significant and positive relationship ( $\mathrm{b}=.089$ and $\mathrm{p}=.002)$, relationship between training and cost effectiveness has a positive and significant relationship $(b=-.213$ and $\mathrm{p}=.003$ ), relationship between accountability and cost effectivenesshas a positive and significant relationship $(\mathrm{b}=.231$ and $\mathrm{p}=.002)$ since all calculated p-values are lesser than 0.05 level of significance. Thus, they prove a positive and significant relationship between $\mathrm{M} \& \mathrm{E}$ and cost effectiveness of Monitoring and Evaluation and Project Performance in Rwanda.

Table 4. 10: Model Summary of M\&E and Timely completion of project

\begin{tabular}{ccccc}
\hline Model & R & R Square & Adjusted R Square & Std. Error of the Estimate \\
\hline $.910^{\mathrm{a}}$ & .828 & .823 & .39629 \\
\hline
\end{tabular}

a. Predictors: (Constant), Accountability, Budgeting, Training

Source: Research Data, 2021

The Table 4.10 proves the $\mathrm{R}$ coefficient .910 indicates $\mathrm{M} \& \mathrm{E}$ has a connection with timely completion of the project as an indicator of project performance in Rwanda. The coefficient of dedication $.828 \mathrm{R}$ suggests that M\&E explains $82.8 \%$ of the development variability in timely completion of the project of project performance in Rwanda. Thus, insinuates input variables for example accountability, budgeting and training that affect progress $82.8 \%$ of Timely completion of the undertaking of Monitoring and Evaluation and Project Performance in Rwanda

Table 4.11: Analysis of Variance (ANOVA) of M \& E and Timely completion of project

\begin{tabular}{|c|c|c|c|c|c|c|}
\hline Model & & Sum of Squares & Df & Mean Square & $\mathrm{F}$ & Sig. \\
\hline & Regression & 74.188 & 3 & 24.729 & 157.464 & $.000^{\mathrm{b}}$ \\
\hline & Residual & 15.391 & 98 & .157 & & \\
\hline & Total & 89.578 & 101 & & & \\
\hline
\end{tabular}

a. Dependent Variable: Timely completion of the project

b. Predictors: (Constant), Accountability, Budgeting, Training

Source: Research Data, 2021

The results in the Table 4.11 show a significant relationship between $\mathrm{M} \& \mathrm{E}$ and timely completion of the project due to the fact the calculated importance cost 0.00 is lesser than 0.05 level of significance.
Thus, the statistical mannequin waiting for correlation between M\&E and timely completion of the project performance in Rwanda is positive and significant 
Table 4.12: Coefficients of $M \& E$ and Timely completion of project

\begin{tabular}{lllllll}
\hline Model & \multicolumn{2}{l}{ Unstandardized Coefficients } & Standardized Coefficients & T & \multirow{2}{*}{ Sig. } \\
\cline { 2 - 4 } & $\mathrm{B}$ & Std. Error & Beta & & \\
\hline (Constant) & .384 & .075 & & 5.135 & .000 \\
Budgeting & -.071 & .077 & -.073 & -.911 & .005 & .000 \\
Training & .873 & .219 & .892 & 3.989 & .000 \\
Accountability & .077 & .202 & .081 & .381 & .004 \\
\hline
\end{tabular}

a. Dependent Variable: Timely completion of the project

Source: Research Data, 2021

The Table 4.12 indicates that variables of M\&E have positive coefficients that which affect timely completion of the project performance as it is proved by regression model, $Y=\beta_{0}+\beta_{1} X_{1}+\beta_{2} X_{2}+\beta_{3} X_{3}+\varepsilon$ which becomes $\mathrm{Y}=.384+.071 \mathrm{X}_{1}+.873 \mathrm{X}_{2}+.077 \mathrm{X}_{3}$ to prove $M \& E$ and timely completion of the project performance in Rwanda.

The relationship between budgeting and timely completion of the project proves that there is a positive and huge relationship $(b=.071$ and $p=.005)$, relationship between training and timely completion of the project has a positive and significant relationship $(b=.873$ and $p=.000)$, relationship between accountability and timely completion of the projecthas positive and significant relationship $(\mathrm{b}=.077$ and $\mathrm{p}=.004)$ since all calculated $\mathrm{p}$ - values are lesser than 0.05 degree of significance. Thus, this proves a significant relationship between $M \& E$ and timely completion of the horticulture project.

Table 4. 13: Model Summary of $M \& E$ and Level of satisfaction of beneficiaries

\begin{tabular}{lllll}
\hline Model & R & R Square & Adjusted R Square & Std. Error of the Estimate \\
\hline & $.919^{\mathrm{a}}$ & .844 & .839 & .39160 \\
\hline
\end{tabular}

a. Predictors: (Constant), Accountability, Budgeting, Training

Source: Research Data, 2021

The results in the Table 4.13 prove the $\mathrm{R}$ coefficient .919 shows that M\&E has a relationship with Level of satisfaction of beneficiaries of Project Performance in Rwanda. The coefficient of dedication $.844 \mathrm{R}$ rectangular additionally shows that M\&E explains $84.4 \%$ of the development variability in Level of satisfaction of beneficiaries of monitoring and evaluation and Project Performance in Rwanda. Thus, proves that input variables of M\&E for example accountability, budgeting and training that affect progress $84.4 \%$ of Level of satisfaction of beneficiaries of Monitoring and Evaluation and Project Performance in Rwanda.

Table 4. 14: Analysis of Variance (ANOVA) of M\&E and Level of satisfaction of beneficiaries

\begin{tabular}{llllll}
\hline Model & Sum of Squares & Df & Mean Square & F & Sig. \\
\hline Regression & 81.286 & 3 & 27.095 & 176.690 & $.000^{\mathrm{b}}$ \\
Residual & 15.028 & 98 & .153 & & \\
Total & 96.314 & 101 & & & \\
\hline
\end{tabular}

a. Dependent Variable: Level of satisfaction of beneficiaries

b. Predictors: (Constant), Accountability, Budgeting, Training

Source: Research Data, 2021

The results in the Table 4.14 show that there is significant relationship between M\&E and Level of satisfaction of beneficiaries due to the fact the calculated value cost is less than 0.05 level of significance. Thus, the statistical correlation between $M \& E$ and level of satisfaction of beneficiaries is significant. 
Table 4. 15: Coefficients of $M$ \& $E$ and Level of satisfaction of beneficiaries

\begin{tabular}{lllllll}
\hline Model & \multicolumn{2}{l}{ Unstandardized Coefficients } & Standardized Coefficients & T & Sig. \\
\cline { 2 - 5 } & $\mathrm{B}$ & Std. Error & Beta & & 4.792 & .000 \\
\hline (Constant) & .354 & .074 & -.061 & -.800 & .004 & .003 \\
Budgeting & -.061 & .077 & .137 & .642 & .003 \\
Training & .139 & .216 & .835 & 4.108 & .000 \\
Accountability & .822 & .200 &
\end{tabular}

a. Dependent Variable: Level of satisfaction of beneficiaries

Source: Research Data, 2021

The Table 4.15 indicates that M\&E predictors have positive and significant coefficients with an influence on the progress of the level of satisfaction of beneficiaries in the monitoring and evaluation and performance of project. The regression model, $\mathrm{Y}=$ $\beta 0+\beta 1 X 1+\beta 2 X 2+\beta 3 X 3+\varepsilon$ becomes $Y=-.354+$ $.061 \mathrm{X} 1+.139 \mathrm{X} 2+.822 \mathrm{X} 3$ which proves relationship between $\mathrm{M} \& \mathrm{E}$ and level of satisfaction of the beneficiaries.

The relationship between budgeting and level of satisfaction of beneficiaries is positive and significant $(\mathrm{b}=.061$ and $\mathrm{p}=.000)$, a positive and significant relationship between training and level of satisfaction of beneficiaries $(b=-.139$ and $p=.004)$, a positive and significant relationship between accountability and level of satisfaction $(b=.822$ and $\mathrm{p}=.003$ ) since all calculated $\mathrm{p}$-values are lesser than 0.05 stage of significance. Thus, confirms a positive and significant relationship between $M \& E$ practices and the satisfaction of beneficiaries.

The results suggest a significant and positive relationship between monitoring and evaluation practices and satisfaction of beneficiaries which is supported by the study of Abalang (2016) who stipulated that most of the informants were not professional in M\&E and then benefited the on job training (OJB) which enhance employees' specialization in $M \& E$ training that increase the outcomes of the project. In the case of the current study the satisfaction of beneficiaries may be raised by the outcomes of the project as a result of professional M\&E practice.

\section{Conclusion}

The previous researches conducted in this manage and distinction and the standard overall performance of the project, such as Abalang, 2016) and Nasambu (2016), have printed that equipment and methods, which have an effect on budgeting and management, group of workers training and participation of stakeholders affect the overall performance of M\&E systems. The findings have additionally published this; most respondents were no longer $\mathrm{M} \& \mathrm{E}$ specialists; however, they received their abilities through on job training (OJT), which used to be an awful lot applauded. The provision of M\&E vocational coaching to personnel was once reported. Therefore, they concluded that there is a massive tremendous connection between monitoring and assessment and project performance.

By and large, the getting to know effects have shown $M \& E$ has a connection with the performance of the horticultural projects due to the fact that the calculated values of sig states for example, that there is a connection between Budget and Cost Effectiveness $(\mathrm{p}=.724$ and $\mathrm{sig}=.000)$, between budgets and timely completion of the assignment ( $p$ $=.755$ and $\mathrm{sig}=.000)$, between budgets and level of satisfaction of beneficiaries $(\mathrm{p}=.754$ and sig=.000) between Training and Cost effectiveness $(\mathrm{p}=.878$ and sig=.000) between Training and Timely completion of the project $(p=.909$ and $\operatorname{sig}=.000)$ between Training and Level of satisfaction of beneficiaries $(\mathrm{p}=.903$ and sig=.000).

\section{Acknowledgement}

First of all, utmost gratitude to God Almighty for the love and security granted to me in the course of my studies and while conducting this research. Special gratitude goes to Mount Kenya University for having given me a chance to further my studies and above all having allocated the most hardworking and understanding supervisors Dr. James Kant Kamuhanda and Mr. Nathan Nyamwenya who were super valuable to the compilation of this paper work. I cannot forget to thank my family and friends but mostly BRAMIN Ltd for having made this research possible. This research wouldn't have been complete without your acceptance and patience. Lastly but not least, my sincere gratitude to each of my Lecturers whose effort was resourceful.

\section{REFERENCES}

[1] Abalang, J. (2016). Assessment of performance of monitoring and evaluation systems at CARITA Torit in South Sudan. Dissertation of Master of Arts in Project Planning and Management at Catholic University of Eastern Africa. Nairobi, Kenya.

[2] Armstrong, M., \& Baron, A. (2004). Managing performance: performance management in action. London. UK.

[3] Bogere, M. (2015). Understanding research and statistical methods:A guide for East 
African Students and researchers. KampalaUganda: Iqra publication centre.

[4] BRAMIN ltd. (2018). Annual report on monitoring and evaluation.Kayonza, Rwanda.

[5] Crawford, L. \&Nahmias.A. . (2010). Competencies for managing change. International Journal of Project Management 28 (2), 405 -412.

[6] Du Plessis, C. (2005). Action for sustainability: preparing an African plan for sustainable building and construction, Journal of Building Research and Information, 33(5), $405-415$.

[7] Family Health Institute. (2004). Monitoring and evaluation of Behavioral change communication programmes. USA: Washington D.C: FHI.

[8] Government of Rwanda. (2010). Monitoring and Evaluation.Perspective indicator of projects performance. Kigali: Rwanda.

[9] Gorgens, M. \&Kusek, J. (2009). Making Monitoring and Evaluation Systems Work,. USA: World bank.

[10]IFAD. (2005). Direct Supervision Pilot Programme: Corporate-level evaluation. Rome: Report No.1687. Office of Evaluation.
[11] Jaszczolt K., Potkanski T. \& Stanislaw, A. (2010). Internal Project M\&E System and Development of Evaluation Capacity Experience of the World Bank - Funded Rural Development Program. USA: World Bank.

[12] Jones, N. (2009). Improving Impact Evaluation Coordination and Use. A Scoping study comprojected by the DFID Evaluation Department on behalf of NONIE.DFID : NONIE.

[13] Kusek, Jody Zall, Rist\& Ray C. . (2004). A Handbook for Development Practitioners: The Steps to A Result-Based Monitoring And Evaluation System. . The World Bank,: Washington, D.C.

[14]Muller \&Turner . (2010). Leadership competency profiles of successful project managers. . International Journal of Project Management Vol 28 , pp: 437 - 488.

[15] Wachamba E. W. (2009). Determinants of Effective Monitoring and Evaluation Systems in Non-Governmental Organizations within Nairobi County, Kenya. Unpublished master thesis.

[16]Zwikael, O., \&Smyrk, J. (2015). Project governance: Balancing control and trust in dealing with risk. International Journal of Project Management, 33(4), 852-862. 